\title{
A COMPARATIVE ANALYSIS OF HUB CONNECTIONS OF EUROPEAN AND ASIAN AIRPORTS AGAINST MIDDLE EASTERN HUBS IN INTERCONTINENTAL MARKETS
}

\author{
Christopher Piltz \\ University of Edinburgh Business School \\ EH8 9JS Edinburgh, United Kingdom \\ christopher.piltz@t-online.de \\ Augusto Voltes-Dorta \\ University of Edinburgh Business School \\ EH8 9JS Edinburgh, United Kingdom \\ avoltes@ becarios.ulpgc.es \\ Pere Suau-Sanchez \\ Cranfield University. \\ Centre for Air Transport Management \\ MK43 0TR, Bedfordshire, United Kingdom \\ p.suausanchez@cranfield.ac.uk
}

\begin{abstract}
In a context of changing trends in global air passenger demand and strong airport and airline competition, the largest US carriers have challenged the quality of the flight connections provided by Middle Eastern hubs in direct competition with their own connections provided via European or Asian airports. Using schedules and bookings data between 2012 and 2016, we assess whether European and Asian hubs have lost market share to Middle East airports in the markets from the Eastern US to South Asia and South East Asia. Thereafter, we provide a comparative analysis of the quality of flight connections for selected European, Asian, and Middle Eastern airports, based on indicators like total frequencies, travel times, and connecting times (determined with a connections-building algorithm). The results provide insights on the threat posed by Middle East airports and airlines that have managerial and policy implications.
\end{abstract}

Keywords: Airport connectivity, hub competition, airline network development

\section{INTRODUCTION}

In recent years, Middle East airlines have leveraged their privileged geographical location and obtained a competitive advantage in intercontinental air transport markets (Zhang, 2015). This advantage is largely built upon a competitive cost structure, a strong brand image, and an efficient hub-and-spoke operation (O'Connell, 2011). This last characteristic makes Middle Eastern airports able to support a large amount of potential flight connections between other origin and destination airports with optimal travel times for the passengers. The impact of the entry of Emirates, Etihad, and Qatar Airways in air transport markets between Europe, Asia, Africa, and the Americas has been noted by many studies, with particular focus on the head-on competition with European and North American airlines (Durganhee, 2013; Dresner, et al., 2015; Kindergan, 2015). Taking into account the strong relationship between the growth of a network carrier and the development of its main hub, it is not surprising that the hegemony of European airports as intercontinental gateways has been challenged by the rise of Middle Eastern hubs, such as Dubai, Doha, and Abu Dhabi (The Telegraph, 2015; Morgan Stanley, 2015).

Few existing papers have analysed hub competition on a global level using quantitative methods. The main conclusion is that the more recent data employed by the authors, the higher the threat of Middle Eastern airports and airlines to its European and American counterparts. Using data from 
2008, Grimme (2011) analysed the impact of the entry of Emirates in the air transport markets between Germany and Asia. He concluded that entry stimulated passenger traffic but incumbents did not lose market share as the new services-with longer travel times via e.g. Dubai-did not constitute a perfect substitute for time-sensitive passengers. Redondi et, al., (2011), also with data from 2008, found that competition amongst major global hubs is high, even between airports located in different countries. However, major European airports still dominated most markets, compared to American and Asian competitors, due to their geographical competitive advantage. More recently, Grosche and Klophaus (2015) used data for 2009-2012 and found that the five leading European hubs (Heathrow, Paris-CDG, Frankfurt, Amsterdam, and Madrid) were still dominating the intercontinental markets despite increased competition from Gulf carriers and the explosive growth of Istanbul-Ataturk. No Gulf-based hub ranked among the five main competitors in regards to connecting traffic in intercontinental markets. The threat arising from Middle East airports and airlines seems to have increased over time, though little has been published with data from 2012 onwards. We can only mention the paper by Suau-Sanchez, et al., (2016) who found that, by 2013, airports like Dubai and Doha were amongst the main competitors at the time of providing flight connections between the UK and the rest of the world.

While the broad air transport literature is very clear about the threat posed by Middle Eastern hubs, there are no quantitative studies that establish if airports like Dubai, Doha, Abu Dhabi, or even Istanbul have already overtaken the largest European hubs in terms of intercontinental passenger connections. We submit that the strong growth of Istanbul and other Middle Eastern hubs between 2012 and 2015 warrants a new analysis of this topic using more recent data than the previous studies. In particular, there is no information about how much market share has leaked between airports. This is our first area of contribution. According to annual passenger traffic (see Figure 1), during the last three years Doha has overtaken Zurich and Vienna, Istanbul has overtaken Amsterdam and Frankfurt, and Dubai has overtaken Frankfurt, Dubai, and Heathrow to rank as the third busiest airport in the world in 2015, just behind Beijing and Atlanta (ACI, 2016). These developments are likely to produce different airport rankings than the ones obtained with data from 2012 or earlier.

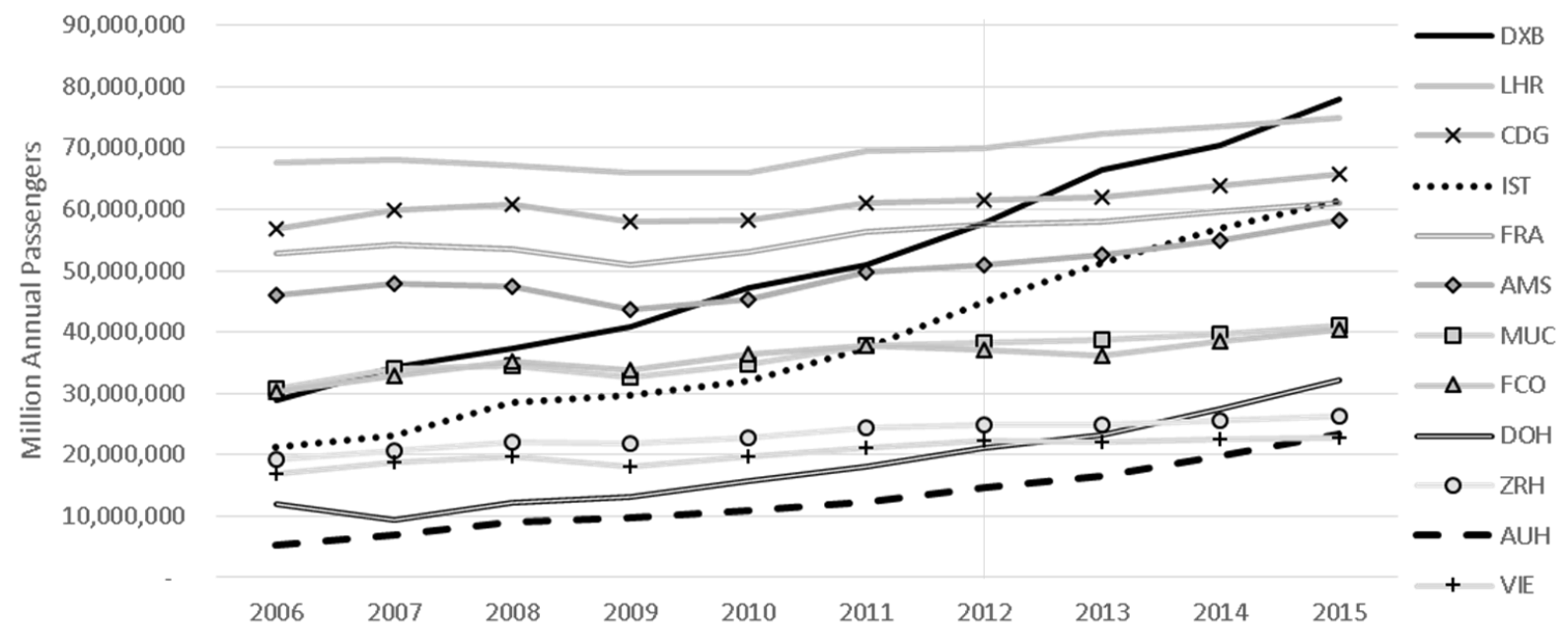

Figure 1. Evolution of annual passenger traffic at selected airports. Source: Airports Council International

In line with the expansion policy of Middle East airlines and airports, several European airlines increasingly complain of an 'unlevel playing field' linked to economic and institutional conditions 
in the Gulf States and demand protection from their respective governments (de Wit, 2014). Similarly, major carriers like American Airlines, Delta, United, and other industry bodies in the US created the Partnership for Open and Fair Skies with the objective to 'restore a level playing field under the Open Skies agreements with Qatar and the UAE', with particular focus on uncovering the government subsidies received by the Gulf carriers (Partnership for Open and Fair Skies, 2015). One of the arguments brought forward by this Partnership is that connections between Eastern US and South East Asia via the Middle East result in longer travel distances than routings provided by US airlines and their partners via Asian hubs (Partnership for Open and Fair Skies, 2015, pp. 47-48). These Middle Eastern routes also stand in direct competition of connections provided by European partners via their hubs, for which the Partnership noted a sustained decrease in traffic (Partnership for Open and Fair Skies, 2015, p. 48). A similar negative impact on traffic was noted in the market to India (Partnership for Open and Fair Skies, 2015, p. 46). These statements, albeit brief, can be interpreted as a challenge to the quality of flight connections offered via the Middle East, with direct implications on Asian and European airports, respectively. Given the lack of academic publications to support or reject this challenge, as a second contribution we aim to shed light on whether the quality of flight connections offered by Middle East hubs in the aforementioned markets is comparable to the quality offered by US airlines and their partners via European and Asian hubs.

From a methodological perspective, many studies have tackled the issue of how to measure airport hub connectivity ${ }^{1}$, such as e.g. Burghouwt (2007) and Burghouwt \& De Wit (2005). A well-known approach employs data on airline schedules to determine the amount and quality of the flight transfers available at each hub. For example, the NETSCAN method (Veldhuis, 1997) builds potential flight combinations and performs a quality-weighted aggregation (linked to the detour imposed with respect to non-stop travel) to calculate the airport's total number of connection units. These travel detours are measured in time units and have two components: 1) additional flying time (also known as circuitry time) and 2) connecting time, with a maximum detour threshold typically imposed to discard uncompetitive connections. In order to account for the fact that long-distance travellers will be less sensitive to travel detours, variable thresholds are imposed depending on travel distance (See e.g. Global Connectivity Index by Allroggen et al., 2015). In this context, an airport's effectiveness as a hub will be largely determined by whether flights arrive to and depart from the hub in coordinated waves (Burghouwt \& De Wit, 2005), which has the desirable effect of maximizing transfer potential and minimizing transfer times. Factors that facilitate the implementation of an optimal wave structure are geographic location, available capacity, terminal layout, noise regulations, or airline dominance (Doganis, 2009).

Since schedules data provides information on the supply of seats at each airport, the methods described above can be referred to as 'supply-based'. We argue, however, that this approach limits the ability to assess hub competition because supply data bears no information on how passengers are actually using those potential connections. One way to complement supply-based indicators is to bring demand data into the analysis, i.e. information on passenger bookings that indicate the airports in which connections have actually been made (e.g. MIDT or PaxIS are two of the most well-known databases). This allows for a precise measurement of the number of passengers in each origin and destination (OD) market as well as their hub preferences. Examples of demand-based

\footnotetext{
${ }^{1}$ Many past studies have employed indicators of centrality or accessibility as a proxy for airport connectivity. This includes degree and betweenness centrality (Guimerà, et al., 2005), or shortest/quickest-path-length centrality and accessiblity (Shaw, 1993; Shaw \& Ivy, 1994; Cronrath, et al., 2008; Malighetti, et al., 2008; Paleari, et al., 2008).
} 
approaches include Grimme (2011) and Rodríguez-Déniz, et al., (2013), which measure the proportion of connecting passengers served by a hub with respect to the total passengers travelling in connecting routes within a given market. Simply put, the authors measure each hub's 'market share' of passenger connections. A comparative analysis of these market shares allows us to assess the strength of hub competition and, in our context, to translate the threat posed by Middle Eastern hubs into a loss of market share for European and Asian airports.

In order to analyse both hub competition and quality of flight connections, a combined approach with supply and demand data is proposed. This will be implemented in two stages: 1) using the supply data to build valid flight connections and identify the travel times provided at each hub for all relevant airport-pair markets, and 2) using the demand data to measure how much traffic currently served by European and Asian hubs could have travelled faster via the Middle East. The combined approach delivers more detail than previous studies by allowing us to disaggregate our results according to geographical markets, which opens the door for airports to have different rankings depending on the strengths and weaknesses of their global destination networks. This can help to establish priorities for improvement based on the importance of the markets and routes where competition is present. These are novel contributions to the literature on hub competition.

Within this context, the main objective of this paper is to determine if Middle East hubs did finally overtake the major European airports in terms of intercontinental passenger connections between 2012 and 2016, as well as to compare their position against established Asian hubs. To that end, several MIDT datasets of passenger bookings covering routes from Eastern US to South Asia and South East Asia are employed to measure each hub's market shares across the sample years. While the focus on the Eastern US as origin region is linked to the US airlines' published claims, it also makes our analysis more straightforward by limiting the role of European, Asian, and Middle Eastern hubs to serve only as intermediate gateways. The aforementioned Asian sub-markets are also a convenient choice because they are the ones in which Middle East airports and airlines compete head-on with their European and Asian counterparts for long-haul passenger connections in relatively similar conditions of geographic detour ${ }^{2}$. Table 1 shows the breakdown of international passenger traffic from the Eastern US according to destination region. The data shows that, while passenger volumes in the selected markets are relatively low in comparison with other destinations, South East Asia and South Asia are among the regions with the largest shares of indirect travel.

Table 1. Breakdown of passenger traffic from the Eastern US according to destination region (June 2016)

\begin{tabular}{lcrrr}
\hline Destination region & weekly passengers & non-stop & indirect & \% indirect \\
\hline South East Asia & 17,642 & 889 & 16,753 & $95.0 \%$ \\
Oceania & 7,435 & 738 & $90.1 \%$ \\
South Asia & 30,979 & 3,267 & 27,712 & $89.5 \%$ \\
Sub-Saharan Africa & 17,706 & 3,664 & 14,042 & $79.3 \%$ \\
Central Asia & 912 & 233 & 679 & $74.5 \%$ \\
non-EEA Europe & 18,289 & 5,103 & 13,186 & $72.1 \%$ \\
Maghreb & 2,779 & 874 & 1,905 & $68.5 \%$ \\
Middle East & 36,191 & 14,930 & 21,261 & $58.7 \%$ \\
Far East & 70,659 & 29,493 & 41,166 & $58.3 \%$ \\
South America & 108,272 & 51,851 & 56,421 & $52.1 \%$ \\
European Economic Area & 306,415 & 166,858 & 139,557 & $45.5 \%$ \\
Central America and Caribbean & 365,090 & 233,779 & 131,311 & $36.0 \%$ \\
\hline
\end{tabular}

In relation to the US airlines' claims about quality of flight connections, a second objective is to determine whether European and Asian airports actually provide better travel times than Middle East hubs in the sample markets. We mix flight schedules and minimum connecting times data

${ }^{2}$ Particularly in comparison with the markets from North America to Africa. 
from June 2016 to develop a connections-building algorithm that identifies optimal travel times for the observed MIDT itineraries. The results will have managerial implications, particularly in regards to airline network management and its impact on the relevant hubs' competitive position.

The rest of the paper is structured as follows. Section 2 describes the dataset and methodology, with particular focus on our indicators. Section 3 presents the results and discusses their main implications. Finally, Section 4 summarizes the main conclusions.

\section{DATA AND METHODOLOGY}

\subsection{Supply and Demand datasets}

The demand side is covered by two MIDT datasets containing airline bookings for an average week in June 2012 and June 2016. The MIDT records contain information on the ticketing airline, points of origin and destination, connecting airports (up to two intermediate stops), and number of bookings. The original sources of information for the MIDT datasets are Global Distribution Systems (GDSs) such as Amadeus, Galileo or Sabre, though they have been processed by the data provider OAG in order to adjust for the tickets bought by direct channels. The validity of these adjustments has been discussed in previous papers that made use of them to analyze airport flight connections in similar contexts (e.g. Suau-Sanchez, et al., 2016).

Each dataset covers one of the two selected markets: 1) Eastern US to South Asia, 2) Eastern US to South East Asia. Due to the high degree of symmetry in intercontinental traffic flows, the market definition is directional in order to reduce computational costs. Figure 2 shows the geographic distribution of the largest originating, destination, and hub airports in the selected markets. The origin airports in the Eastern US are those geographically located in the Eastern Time Zone ${ }^{3}$. Additional US airports included are those that mainly play a role as hubs in transpacific routes like Los Angeles and San Francisco. South Asia comprises India, Bangladesh, Pakistan, Maldives, and Sri Lanka. South East Asia comprises Brunei, Cambodia, East Timor, Indonesia, Laos, Malaysia, Myanmar, Philippines, Singapore, Thailand, and Vietnam. Among the hub regions, note that Europe is split between European Economic Area (EEA) and non-EEA Europe, primarily to separate the performance of Istanbul Ataturk (non-EEA) from the legacy EEA hubs. In regards to the Asian hubs, we focus on the Far East, which includes China, Taiwan, Japan, and South Korea since they can be neither origins nor destinations in the chosen market.

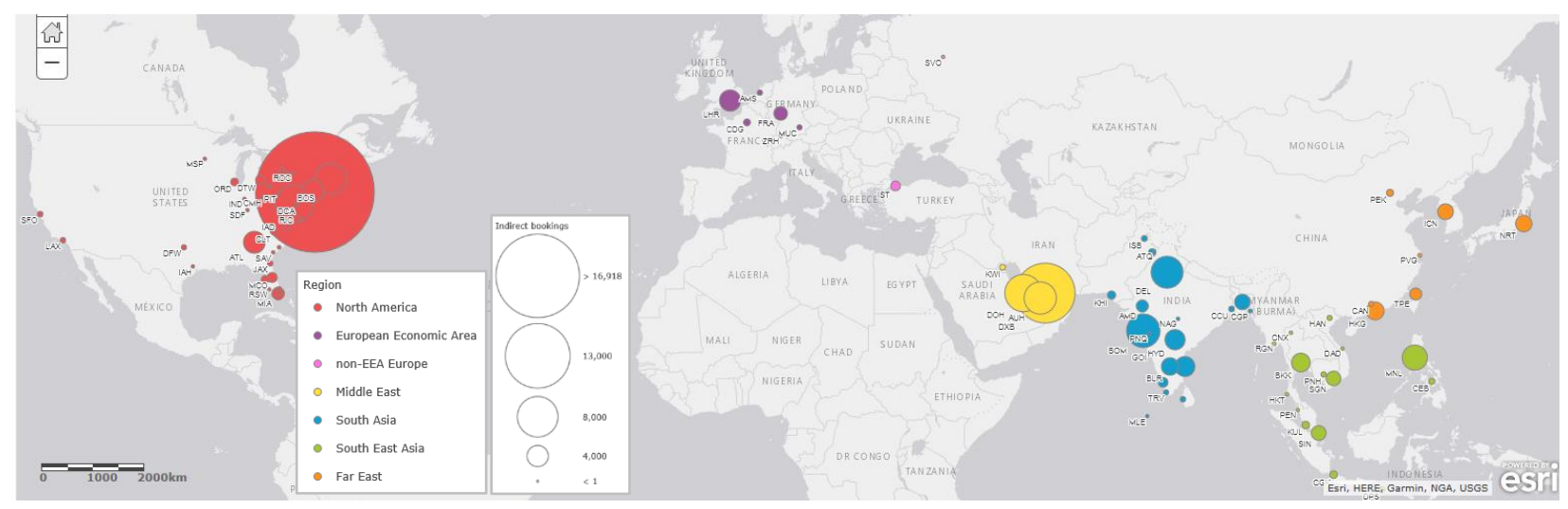

Figure 2. Largest origin, destination, and hub airports in selected markets according to region (June 2016)

\footnotetext{
${ }^{3}$ Hence, airports in the states of Michigan, Indiana, Kentucky, Tennessee, and Florida located in the central time zone are excluded as points of origin.
} 
Table 2 provides the most recent traffic figures for the individual airports and countries (June 2016). It is worth noting that both markets present very high rates or indirect travel and the intermediate position of the three hub regions under study facilitates comparability between the individual hubs. For ease of presentation, only a selection of major hubs (based on traffic counts) will be included in our detailed results since the vast majority of airports serving as intermediate gateways in intercontinental markets actually handle very small amounts of passengers. The hubs included in the analysis are, for the EEA region: Frankfurt (FRA), Heathrow (LHR), Paris (CDG), Amsterdam (AMS), Munich (MUC), Brussels (BRU), and Zurich (ZRH); for the non-EEA countries: Istanbul Ataturk (IST); for the Middle East: Dubai (DXB), Abu Dhabi (AUH), and Doha (DOH); for the Far East region: Tokyo Narita (NRT), Hong Kong (HKG), Seoul Incheon (ICN), Taiwan (TPE), Singapore (SIN), Shanghai Pudong (PVG), and Tokyo Haneda (HND). Looking at the geography of this sample of airports, one can expect the Middle East to compete head-on with European hubs for transatlantic routes to South Asia, and primarily against transpacific routes via Far Eastern hubs in the South East Asian markets.

Table 2. Breakdown of passenger traffic per destination country and top origin and destination airports (June 2016)

\begin{tabular}{|c|c|c|c|c|c|c|c|}
\hline $\begin{array}{l}\text { Destination } \\
\text { Country }\end{array}$ & $\begin{array}{r}\text { Weekly } \\
\text { arrivals }\end{array}$ & $\begin{array}{c}\text { Indirect } \\
\text { arrivals }\end{array}$ & $\begin{array}{l}\% \\
\text { indirect }\end{array}$ & $\begin{array}{l}\text { Destination } \\
\text { Airport }\end{array}$ & $\begin{array}{r}\text { Weekly } \\
\text { arrivals }\end{array}$ & $\begin{array}{l}\text { Departure } \\
\text { Airport }\end{array}$ & $\begin{array}{r}\text { Weekly } \\
\text { departures }\end{array}$ \\
\hline India & 25,695 & 22,836 & $88.9 \%$ & Mumbai (BOM) & 6,068 & New York JFK (JFK) & 19,101 \\
\hline Pakistan & 2,503 & 2,095 & $83.7 \%$ & Delhi (DEL) & 5,657 & Washington Dulles (IAD) & 5,748 \\
\hline Bangladesh & 2,176 & 2,176 & $100.0 \%$ & Manila (MNL) & 4,785 & Newark (EWR) & 4,548 \\
\hline Sri Lanka & 550 & 550 & $100.0 \%$ & Hyderabad (HYD) & 3,303 & Boston (BOS) & 3,369 \\
\hline Maldives & 55 & 55 & $100.0 \%$ & Bangkok (BKK) & 2,977 & Atlanta (ATL) & 2,830 \\
\hline Total South Asia & 30,979 & 27,712 & $89.5 \%$ & Chennai (MAA) & 2,803 & Orlando (MCO) & 1,718 \\
\hline Philippines & 5,613 & 5,114 & $91.1 \%$ & Singapore (SIN) & 2,613 & Miami (MIA) & 1,563 \\
\hline Thailand & 3,297 & 3,297 & $100.0 \%$ & Bengaluru (BLR) & 2,551 & Detroit (DTW) & 1,080 \\
\hline Vietnam & 2,797 & 2,753 & $98.4 \%$ & Ho Chi Minh City (SGN) & 2,239 & Tampa (TPA) & 913 \\
\hline Singapore & 2,613 & 2,267 & $86.8 \%$ & Ahmedabad (AMD) & 2,071 & Raleigh/Durham (RDU) & 887 \\
\hline Indonesia & 1,545 & 1,545 & $100.0 \%$ & Dhaka (DAC) & 2,009 & Charlotte (CLT) & 866 \\
\hline Malaysia & 935 & 935 & $100.0 \%$ & Kochi (IN) (COK) & 1,176 & Philadelphia (PHL) & 668 \\
\hline Cambodia & 518 & 518 & $100.0 \%$ & Lahore (LHE) & 1,054 & Fort Lauderdale (FLL) & 475 \\
\hline Myanmar & 273 & 273 & $100.0 \%$ & Jakarta (CGK) & 858 & Jacksonville (JAX) & 465 \\
\hline Laos & 41 & 41 & $100.0 \%$ & Karachi (KHI) & 846 & Cleveland (CLE) & 440 \\
\hline Brunei & 8 & 8 & $100.0 \%$ & Kuala Lumpur(KUL) & 821 & Columbus (CMH) & 341 \\
\hline East Timor & 2 & 2 & $100.0 \%$ & Cebu (CEB) & 634 & Cincinnati (CVG) & 306 \\
\hline Total South East Asia & 17,642 & 16,753 & $95.0 \%$ & Kolkata (CCU) & 619 & Pittsburgh (PIT) & 268 \\
\hline Grand Total & 48,621 & 44,465 & $91.5 \%$ & Denpasar Bali (DPS) & 561 & Washington Reagan (DCA) & 251 \\
\hline
\end{tabular}

Source: MIDT, Own elaboration

The supply side is covered by a dataset of worldwide flight schedules during the first week of June 2016, for which the primary source is the OAG Schedules dataset. After simple data processing, the supply dataset comprises 697,411 unique records of scheduled passenger flight departures. Each record indicates the operating airline, alliance membership (if applicable), flight number, origin and destination airport codes, aircraft type, number of seats, flight distance, and Universal Time Coordinated (UTC) departure and arrival times. In addition, we also obtained a dataset of airport-specific minimum connecting times, including around 70,000 airline-specific exceptions valid on June 2016. This was obtained from the OAG Connections Analyser.

\subsection{Methodology and indicators}

A few indicators will be used to assess hub competition and compare the quality of hub connections of the sample airports. In similar fashion than previous demand-based studies (e.g. Grimme, 2011; Rodríguez-Déniz, et al., 2013), the importance of a hub airport in a given market is measured by its individual share of connecting passengers over the total passenger connections. If we understand our bookings data as a set of $j$ itineraries, each one serving a given market $k$, and passing through 
a hub $i$, then our "share of connections" indicator per hub and market $\left(C_{i k}\right)$ can be defined as Equation 1.

(1) $C_{i k}=\frac{\sum_{j} \text { connecting passengers }_{i j k}}{\sum_{j} \text { connecting passengers }_{j k}}$

To complement that indicator, we also add the market's overall connecting rate (share of indirect over total traffic) in order to discuss whether the entry of Middle East hubs has had an impact on the proportion of indirect vs direct travel in the sample period.

The analysis of the quality of hub connections is based on the best available weekly flight connections for each of the MIDT passenger itineraries, as well as on the allocation of actual passenger bookings to these travel options. In order to find valid flight connections, there is need to match supply (airline schedules) and demand datasets across a sample week. A connectionsbuilding algorithm was employed to that end (details are provided in Appendix A). The resulting updated travel records are then used to compute three indicators of quality of hub connections at an origin-and-destination airport-pair level: total travel time, total flying time, and total connecting time at the hub. The disaggregation of total travel time in its two components allows us to analyze both the degree of circuitry imposed by the indirect itinerary and the length of the transfer provided by each hub against its competitors. Given the lack of non-stop itineraries in the vast majority of airport-pairs in the selected markets, we do not calculate detour factors with respect to non-stop travel times. The relative circuitry imposed by a particular routing can be discussed by comparing a hub's performance against its competitors. An illustrative example of this range of indicators for the busiest airport pair, New York (JFK) to Mumbai (BOM), is shown in Table 3, with the hubs ranked according to total travel time.

Table 3. Hub choices in the market between JFK and BOM

\begin{tabular}{|c|c|c|c|c|c|c|c|c|}
\hline$\overline{\text { rank }}$ & Hub Airport & Code & Region & $\begin{array}{c}\text { Weekly } \\
\text { Frequencies }\end{array}$ & $\begin{array}{c}\text { Flight Time } \\
(\min )\end{array}$ & $\begin{array}{l}\text { Connecting } \\
\text { Time (min) }\end{array}$ & $\begin{array}{c}\text { Travel Time } \\
\text { (min) }\end{array}$ & $\begin{array}{c}\text { Weekly } \\
\text { Bookings }\end{array}$ \\
\hline 1 & London Heathrow & LHR & EEA & 6 & 955 & 60 & 1,015 & 135 \\
\hline 2 & Dubai & DXB & Middle East & 6 & 930 & 105 & 1,035 & 447 \\
\hline 3 & Frankfurt & FRA & EEA & 6 & 935 & 125 & 1,060 & 45 \\
\hline 3 & London Heathrow & LHR & EEA & 2 & 965 & 95 & 1,060 & 34 \\
\hline 4 & London Heathrow & LHR & EEA & 5 & 965 & 100 & 1,065 & 95 \\
\hline 5 & Zurich & ZRH & EEA & 6 & 975 & 105 & 1,080 & 55 \\
\hline 6 & London Heathrow & LHR & EEA & 6 & 990 & 100 & 1,090 & 6 \\
\hline 7 & Amsterdam & AMS & EEA & 6 & 995 & 120 & 1,115 & 18 \\
\hline 8 & Paris CDG & CDG & EEA & 6 & 970 & 150 & 1,120 & 30 \\
\hline 9 & Abu Dhabi & AUH & Middle East & 12 & 1,005 & 125 & 1,130 & 520 \\
\hline 10 & Doha & DOH & Middle East & 6 & 960 & 190 & 1,150 & 136 \\
\hline 11 & Istanbul Ataturk & IST & Non-EEA & 6 & 970 & 185 & 1,155 & 36 \\
\hline 12 & Dubai & DXB* & Middle East & 5 & 993 & 85 & 1,165 & 5 \\
\hline 12 & Boston Logan & BOS* & North America & 5 & 993 & 87 & 1,165 & 5 \\
\hline 13 & Dubai & DXB* & Middle East & 2 & 1,006 & 130 & 1,190 & 2 \\
\hline 13 & Boston Logan & BOS* & North America & 2 & 1,006 & 54 & 1,190 & 2 \\
\hline 14 & Munich & MUC & EEA & 6 & 970 & 225 & 1,195 & 24 \\
\hline 15 & Kuwait & KWI & Middle East & 2 & 990 & 245 & 1,235 & 103 \\
\hline 16 & Cairo & CAI & Middle East & 3 & 980 & 310 & 1,290 & 6 \\
\hline 17 & Manchester & MAN* & EEA & 6 & 1,100 & 105 & 1,320 & 6 \\
\hline 17 & Abu Dhabi & AUH* & Middle East & 6 & 1,100 & 115 & 1,320 & 6 \\
\hline 18 & Tel Aviv & TLV & Middle East & 1 & 1,115 & 260 & 1,375 & 2 \\
\hline 19 & Delhi & DEL* & South Asia & 1 & 1,030 & 235 & 1,410 & 2 \\
\hline 19 & Amsterdam & AMS* & EEA & 1 & 1,030 & 145 & 1,410 & 2 \\
\hline 20 & Hong Kong & HKG & Far East & 3 & 1,340 & 75 & 1,415 & 3 \\
\hline
\end{tabular}


Number of weekly frequencies, passenger bookings, average flight times, connecting times, and travel times are calculated for each hub region in the market. Both unweighted (i.e. supply-based) and passenger-weighted (i.e. supply-and-demand) averages are calculated. Then, the information in the table above is further disaggregated in days of operation (from Monday to Sunday of our sample week) according to the initial departure time of the passengers in the US. A new comparative analysis is made at an airport-pair-day level. The indicators provided for each hub are 1) the proportion of passengers served in direct competition with at least one hub from another region, and 2) the proportion of passengers for which a competing hub from another region does not offer a faster itinerary ${ }^{4}$. These two indicators also combine supply and demand data, with the goal to capture the impact of head-to-head competition (or lack thereof) in a more direct way. In addition, it directly serves our research objective of comparing the quality of hub connections (in terms of total travel times) between hubs in different geographical areas as it would be judged by a passenger making a choice of itinerary based on travel times within a given day of departure.

An illustrative example of this kind of analysis for the JFK-BOM airport pair is shown in Table 4. In this market, the European hubs clearly outperform over the Middle Eastern ones, despite the similar flight times, due to shorter average connecting times. Furthermore, only $6 \%$ of passengers travelling via the Middle East did not have a faster travel option on the same day via a European or Asian hub, in comparison with the $43 \%$ of passengers travelling via Europe, which could not have chosen a faster itinerary via the Middle East.

Table 4. Comparison of hub regions in the market between JFK and BOM

\begin{tabular}{|c|c|c|c|c|c|c|c|c|c|c|}
\hline \multirow{2}{*}{$\begin{array}{l}\text { JFK to BOM } \\
\text { Hub region } \\
\end{array}$} & \multirow[t]{2}{*}{$\begin{array}{l}\text { Weekly } \\
\text { Frequencies }\end{array}$} & \multicolumn{2}{|c|}{ Avg. Flight Time (min) } & \multicolumn{2}{|c|}{$\begin{array}{c}\text { Avg. Connecting Time } \\
(\text { min })\end{array}$} & \multicolumn{2}{|c|}{$\begin{array}{l}\text { Avg. Travel Time } \\
(\text { min) }\end{array}$} & \multirow[t]{2}{*}{$\begin{array}{l}\text { Avg. pax per } \\
\text { frequency }\end{array}$} & \multirow{2}{*}{$\begin{array}{r}\text { \% pax served in } \\
\text { competition } w / \\
\text { other regions }\end{array}$} & \multirow{2}{*}{$\begin{array}{r}\% \text { pax not } \\
\text { slower than } \\
\text { competing } \\
\text { regions }\end{array}$} \\
\hline & & unweighted & weighted & Unweighted & weighted & unweighted & weighted & & & \\
\hline$\overline{\text { EEA Europe }}$ & 56 & 1,025 & 967 & 127 & 102 & 1,152 & 1,069 & 32 & $100 \%$ & $43 \%$ \\
\hline Middle East & 43 & 1,036 & 973 & 174 & 136 & 1,210 & 1,108 & 136 & $100 \%$ & $6 \%$ \\
\hline Non-EEA Europe & 6 & 970 & 970 & 185 & 185 & 1,155 & 1,155 & 36 & $100 \%$ & $0 \%$ \\
\hline Far East & 3 & 1,340 & 1,340 & 75 & 75 & 1,415 & 1,415 & 3 & $100 \%$ & $0 \%$ \\
\hline
\end{tabular}

The results at an airport-pair level are aggregated at a country and regional level using the same indicators in order to provide the higher-level analysis of quality of hub connections that fulfills the objectives of this paper. The country and regional tables are presented in the next section.

\section{RESULTS AND DISCUSSION}

\subsection{Evolution of hub connections}

Table 5 shows the change in the "share of connections" indicator $\left(C_{i k}\right)$ for the selected airports and markets between 2012 and 2016. In all scenarios, the 12 selected hubs accumulate more than $80 \%$ share of the connections in the sample markets. The main conclusion is that Middle Eastern hubs have indeed increased their share of connections at the expense of European airports. This dominance can be explained by the expansion of airport infrastructure and the growth strategy implemented by carriers like Emirates. In the Eastern US-South Asia market, we can see how Dubai, Abu Dhabi, and Doha have overtaken Heathrow as the leaders according to the proportion of connecting passengers. In fact, Heathrow is the European hub that has lost the most market share, yet it is also worth noting the case of Brussels that has virtually disappeared from this market. During the sample period there were several developments that justify this explosive growth: a) Jet Airways became equity partner of Etihad, b) bilateral agreements between UAE and India allowed for new access points (according to our data, the number of onward points in South Asia served

\footnotetext{
${ }^{4}$ Passengers served without competition are included here as well.
} 
from Dubai and Abu Dhabi increased from 19 to 29 between 2012 and 2016), and also increased capacity was allowed (the Emirates' A380 was included in said bilateral agreement). The evolution of connecting rates in this market shows a 5.9\% increase in the proportion of indirect travel, which is parallel to market growth as the absolute number of non-stop passengers remained relatively stable. At first sight, this could be interpreted as a sign that the Gulf carriers' one-stop product is generating new demand (as mentioned by Grimme, 2011) and thus not predating non-stop connectivity. However, in the absence of a more elaborated counterfactual scenario (same market without Middle East travel options), that conclusion is beyond our present scope of analysis.

In the five sample years, Middle East hubs have also quadrupled their market share in terms of passenger connections in Eastern US-South East Asia routes, again, at the expense of European hubs. In particular, the negative impact has been felt in both Heathrow and Frankfurt that have lost most of their traffic. The increase in market share for Middle Eastern hubs can also be attributed to the intense advertising efforts of both Emirates and Etihad in South East Asia in direct competition with Singapore Airlines' non-stop service to the Eastern US, which, as shown in Table 5 , has also lost most of its share of connections. As a consequence, the data shows a clear leakage of direct passengers towards indirect routes in this market, which explains the $12.8 \%$ increase in the connecting rate. In regard to the concerns expressed by US carriers, airports in the Far East have actually kept their strong leadership in transpacific routes to South East Asia. However, the net impact on European and Asian hubs combined is negative as originally claimed.

Table 5. Evolution of the "share of connections" indicator $\left(C_{i k}\right)$ for selected airports and markets: June 2012-2016.

\begin{tabular}{|c|c|c|c|c|c|c|c|}
\hline South Asia & 2012 & 2016 & $\Delta 12-16(\%)$ & South East Asia & 2012 & 2016 & $\Delta 12-16(\%)$ \\
\hline Dubai (DXB) & $11.6 \%$ & $28.6 \%$ & $16.9 \%$ & Tokyo Narita (NRT) & $24.7 \%$ & $17.6 \%$ & $-7.1 \%$ \\
\hline Abu Dhabi (AUH) & $6.2 \%$ & $16.2 \%$ & $10.1 \%$ & Hong Kong (HKG) & $12.2 \%$ & $15.4 \%$ & $3.2 \%$ \\
\hline Doha $(\mathrm{DOH})$ & $10.0 \%$ & $14.3 \%$ & $4.3 \%$ & Seoul Incheon (ICN) & $14.7 \%$ & $13.2 \%$ & $-1.5 \%$ \\
\hline London Heathrow (LHR) & $26.2 \%$ & $10.8 \%$ & $-15.5 \%$ & Dubai (DXB) & $3.0 \%$ & $10.1 \%$ & $7.1 \%$ \\
\hline Frankfurt (FRA) & $8.8 \%$ & $5.9 \%$ & $-2.9 \%$ & Doha $(\mathrm{DOH})$ & $1.0 \%$ & $8.8 \%$ & $7.9 \%$ \\
\hline Istanbul Ataturk (IST) & $2.3 \%$ & $3.4 \%$ & $1.1 \%$ & Taiwan (TPE) & $4.3 \%$ & $8.7 \%$ & $4.3 \%$ \\
\hline Kuwait (KWI) & $4.2 \%$ & $3.0 \%$ & $-1.2 \%$ & Singapore (SIN) & $8.8 \%$ & $2.6 \%$ & $-6.2 \%$ \\
\hline Paris (CDG) & $4.8 \%$ & $2.0 \%$ & $-2.9 \%$ & Shanghai (PVG) & $1.4 \%$ & $1.9 \%$ & $0.5 \%$ \\
\hline Munich (MUC) & $1.5 \%$ & $1.3 \%$ & $-0.3 \%$ & London Heathrow (LHR) & $4.5 \%$ & $1.8 \%$ & $-2.6 \%$ \\
\hline Amsterdam (AMS) & $3.8 \%$ & $1.1 \%$ & $-2.6 \%$ & Abu Dhabi (AUH) & $0.3 \%$ & $1.7 \%$ & $1.4 \%$ \\
\hline Zurich (ZRH) & $2.2 \%$ & $1.0 \%$ & $-1.2 \%$ & Tokyo Haneda (HND) & $0.8 \%$ & $0.4 \%$ & $-0.4 \%$ \\
\hline Brussels (BRU) & $4.9 \%$ & $0.0 \%$ & $-4.9 \%$ & Frankfurt (FRA) & $6.8 \%$ & $0.1 \%$ & $-6.7 \%$ \\
\hline Total EEA Europe & $52.9 \%$ & $22.4 \%$ & $-30.5 \%$ & Total EEA Europe & $12.5 \%$ & $3.6 \%$ & $-8.9 \%$ \\
\hline Total Middle East & $32.4 \%$ & $62.3 \%$ & $29.9 \%$ & Total Middle East & $4.8 \%$ & $20.8 \%$ & $16.0 \%$ \\
\hline Total Non-EEA Europe & $2.5 \%$ & $3.7 \%$ & $1.2 \%$ & Total Non-EEA Europe & $0.5 \%$ & $0.9 \%$ & $0.5 \%$ \\
\hline Total Far East & $0.2 \%$ & $0.5 \%$ & $0.2 \%$ & Total Far East & $59.1 \%$ & $63.4 \%$ & $4.3 \%$ \\
\hline Connecting Rate & $83.6 \%$ & $89.5 \%$ & $5.9 \%$ & Connecting Rate & $82.2 \%$ & $95.0 \%$ & $12.8 \%$ \\
\hline
\end{tabular}

Source: MIDT

\subsection{Quality of hub connections}

Table 6 shows the results of the analysis of the quality of hub connections for the South Asia market, with the hubs sorted in the same order (market share) than in Table 5. These figures indicate that the routes available via the Middle East have longer flying times than those available at European hubs due to higher circuitry with respect to non-stop travel. Once the passenger weights are factored in, London Heathrow and Munich airports emerge as the leaders in terms of flying times. The situation is rather different when considering connecting times: Dubai, and Abu Dhabi deliver very competitive connections in this market and clearly beat major European hubs like Heathrow, Frankfurt, and Istanbul. In the search for an explanation, we found a negative correlation $(-29.4 \%)$ between the share of home-carrier alliance connections per hub (measured from our raw data) and the average connecting times recorded in Tables 6 . This can be one of the factors that create an advantage for Middle East hubs in this market, since they tend to operate connections almost exclusively for their home carrier (and alliance partners if applicable), with the resulting 
benefits in terms of scheduling coordination. With a few exceptions, European hubs tend to host more connections by airlines other than those in their respective home-carrier alliances. Once the two components (flying and connecting times) are brought together, Heathrow emerges as the fastest travel option amongst the top-5 hubs, yet, on average, Middle Eastern hubs remain competitive by compensating longer detours with efficient connections. Besides providing very competitive travel options in this market, Middle East carriers benefit from their large amount of connecting frequencies (almost twice the frequencies of all European hubs combined) in order to deliver a consistent offering across airport-pairs and days of operation. As a consequence, they end up operating without competition in many instances. Out of the 548 airport-pairs served indirectly between Eastern US and South Asia, Middle Eastern carriers have no direct competition in 355 (most of them very small markets). This translates into the relatively lower competitive intensity shown in Table 6, with Middle Eastern hubs having $71 \%$ of traffic exposed to competition, while the figure for EEA airports is $89.6 \%$. A consequence of that is Dubai and Doha having the highest proportion of daily passengers served no slower than hubs in other regions. On average, $60.9 \%$ of passengers travelling via the Middle East did not have a faster travel option on the day via a hub in another region. The same figure for EEA hubs is $52.1 \%$ and for non-EEA hubs is $25.4 \%$.

Table 6. Indicators of quality of connections for selected hubs and regions in the South Asian market: June 2016

\begin{tabular}{|c|c|c|c|c|c|c|c|c|c|c|}
\hline \multirow{2}{*}{$\begin{array}{l}\text { Eastern US to South } \\
\text { Asia } \\
\text { Airport/Hub region }\end{array}$} & \multirow[t]{2}{*}{$\begin{array}{l}\text { Weekly } \\
\text { Frequencies }\end{array}$} & \multicolumn{2}{|c|}{ Avg. Flight Time (min) } & \multicolumn{2}{|c|}{$\begin{array}{c}\text { Avg. Connecting Time } \\
(\text { min) }\end{array}$} & \multicolumn{2}{|c|}{$\begin{array}{l}\text { Avg. Travel Time } \\
\text { (min) }\end{array}$} & \multirow[t]{2}{*}{$\begin{array}{l}\text { Avg. pax per } \\
\text { frequency }\end{array}$} & \multirow{2}{*}{$\begin{array}{r}\% \text { pax served in } \\
\text { competition } w / \\
\text { other regions }\end{array}$} & \multirow{2}{*}{$\begin{array}{r}\text { \% pax not } \\
\text { slower than } \\
\text { competing } \\
\text { regions }\end{array}$} \\
\hline & & unweighted & weighted & Unweighted & weighted & unweighted & weighted & & & \\
\hline Dubai (DXB) & 1,422 & 1,179 & 1,052 & 155 & 148 & 1,334 & 1,200 & 4.7 & $72.7 \%$ & $65.1 \%$ \\
\hline Abu Dhabi (AUH) & 997 & 1,228 & 1,088 & 135 & 130 & 1,363 & 1,218 & 3.7 & $73.4 \%$ & $50.0 \%$ \\
\hline Doha (DOH) & 815 & 1,123 & 1,044 & 166 & 169 & 1,289 & 1,212 & 4.4 & $66.1 \%$ & $68.3 \%$ \\
\hline Heathrow (LHR) & 532 & 1,091 & 1,006 & 200 & 160 & 1,291 & 1,166 & 3.8 & $89.1 \%$ & $58.7 \%$ \\
\hline Frankfurt (FRA) & 406 & 1,103 & 1,016 & 277 & 252 & 1,380 & 1,268 & 3.6 & $90.5 \%$ & $39.3 \%$ \\
\hline Istanbul Ataturk (IST) & 183 & 1,053 & 1,012 & 210 & 197 & 1,263 & 1,209 & 4.7 & $96.1 \%$ & $27.3 \%$ \\
\hline Kuwait (KWI) & 20 & 1,055 & 1,017 & 289 & 288 & 1,345 & 1,305 & 21.5 & $72.0 \%$ & $29.8 \%$ \\
\hline Paris (CDG) & 185 & 1,074 & 1,035 & 156 & 151 & 1,231 & 1,186 & 2.2 & $93.2 \%$ & $62.0 \%$ \\
\hline Munich (MUC) & 102 & 1,080 & 1,001 & 157 & 142 & 1,237 & 1,143 & 3.1 & $83.4 \%$ & $65.3 \%$ \\
\hline Amsterdam (AMS) & 133 & 1,085 & 1,029 & 204 & 192 & 1,289 & 1,221 & 1.9 & $86.8 \%$ & $60.7 \%$ \\
\hline Zurich (ZRH) & 97 & 1,119 & 1,023 & 131 & 141 & 1,250 & 1,164 & 2.5 & $94.3 \%$ & $27.9 \%$ \\
\hline EEA Europe & 1,499 & 1,093 & 1,014 & 208 & 186 & 1,301 & 1,200 & 3.2 & $89.6 \%$ & $52.1 \%$ \\
\hline Middle East & 3,268 & 1,157 & 1,049 & 169 & 159 & 1,326 & 1,208 & 4.1 & $71.1 \%$ & $60.9 \%$ \\
\hline Non-EEA Europe & 194 & 1,047 & 1,008 & 214 & 203 & 1,261 & 1,210 & 4.7 & $96.4 \%$ & $25.4 \%$ \\
\hline Far East & 52 & 1,217 & 1,220 & 158 & 162 & 1,375 & 1,382 & 1.2 & $97.7 \%$ & $4.7 \%$ \\
\hline Airport-pairs & 548 & Airpor & air-days & 2,053 & & & & & & \\
\hline
\end{tabular}

Table 7 shows the results of the indicators of quality of hub connections for the South East Asia market, with the hubs sorted in the same order (market share) than in Table 5. The itineraries supplied via Middle Eastern airports have slightly higher detours than the ones offered by the major Asian hubs. However, once passenger traffic weights are factored in, it is found that Dubai provides lower average flying times than the market leader Tokyo Narita. In fact, passengers via Dubai experience virtually the same flying times than the fastest option (Heathrow). The discrepancy between weighted and unweighted averages also applies to connecting times. Dubai falls behind in terms of the connections available at the airport (the home-carrier argument mentioned above does not apply to this market), but it clearly becomes the market leader in relation to the actual passengers served. In this regard, the implication is that the busiest indirect routes at Dubai are also the ones offering shorter connecting times, which brings down the passenger-weighted average. This signals that not all viable flight connections that can be made at an airport are equally valuable from a demand perspective. Furthermore, while past authors (e.g. Veldhuis, 1997) employ supply data to weight que quality of connections based on travel detours, we also observe that routes with the same detour can have drastically different passenger numbers as demand is affected by many other factors (including price). Thus, complementing supply data with information on actual 
demand is a different way to assign value to a particular flight connection, and may lead to different airport rankings.

Finally, day-to-day competition is still dominated by the Asian hubs, with their larger number of frequencies spread over the sample week. About $93 \%$ of passengers travelling via a hub in the Far East to South East Asia could not have found a faster routing via the Middle East or Europe on the same day.

Table 7. Indicators of quality of connections for selected hubs and regions in the South East Asian market: June 2016

\begin{tabular}{|c|c|c|c|c|c|c|c|c|c|c|}
\hline \multirow{2}{*}{$\begin{array}{l}\text { Eastern US to SE } \\
\text { Asia } \\
\text { Hub } \\
\end{array}$} & \multirow[t]{2}{*}{$\begin{array}{l}\text { Weekly } \\
\text { Frequencies }\end{array}$} & \multicolumn{2}{|c|}{$\begin{array}{c}\text { Avg. Flight Time } \\
\text { (min) }\end{array}$} & \multicolumn{2}{|c|}{$\begin{array}{c}\text { Avg. Connecting Time } \\
(\text { min })\end{array}$} & \multicolumn{2}{|c|}{$\begin{array}{l}\text { Avg. Travel Time } \\
\text { (min) }\end{array}$} & \multirow{2}{*}{$\begin{array}{r}\text { Avg. pax } \\
\text { per } \\
\text { frequency }\end{array}$} & \multirow{2}{*}{$\begin{array}{r}\text { \% pax served in } \\
\text { competition } w / \\
\text { other regions }\end{array}$} & \multirow{2}{*}{$\begin{array}{r}\text { \% pax not } \\
\text { slower than } \\
\text { competing } \\
\text { regions }\end{array}$} \\
\hline & & unweighted & weighted & unweighted & weighted & & weighted & & & \\
\hline Tokyo Narita (NRT) & 1,082 & 1,366 & 1,301 & 139 & 134 & 1,506 & 1,435 & 1.8 & $66.1 \%$ & $88.6 \%$ \\
\hline Hong Kong (HKG) & 683 & 1,340 & 1,232 & 154 & 150 & 1,494 & 1,382 & 2.9 & $70.1 \%$ & $89.5 \%$ \\
\hline Seoul Incheon (ICN) & 595 & 1,318 & 1,211 & 160 & 148 & 1,479 & 1,360 & 3.0 & $71.0 \%$ & $97.6 \%$ \\
\hline Dubai (DXB) & 395 & 1,370 & 1,263 & 151 & 123 & 1,521 & 1,386 & 3.4 & $94.1 \%$ & $30.5 \%$ \\
\hline Doha (DOH) & 420 & 1,373 & 1,289 & 218 & 180 & 1,591 & 1,469 & 3.0 & $81.4 \%$ & $36.7 \%$ \\
\hline Taiwan (TPE) & 463 & 1,424 & 1,304 & 161 & 163 & 1,585 & 1,466 & 2.3 & $73.0 \%$ & $96.5 \%$ \\
\hline Singapore (SIN) & 56 & 1,516 & 1,515 & 155 & 165 & 1,671 & 1,680 & 1.0 & - & - \\
\hline Shanghai (PVG) & 80 & 1,392 & 1,287 & 233 & 250 & 1,625 & 1,537 & 2.1 & $75.2 \%$ & $98.2 \%$ \\
\hline Heathrow (LHR) & 141 & 1,278 & 1,260 & 145 & 142 & 1,423 & 1,402 & 1.3 & $91.8 \%$ & $33.8 \%$ \\
\hline Abu Dhabi (AUH) & 112 & 1,401 & 1,339 & 231 & 214 & 1,632 & 1,553 & 2.2 & $91.9 \%$ & $19.0 \%$ \\
\hline Tokyo Haneda (HND) & 20 & 1,450 & 1,450 & 198 & 198 & 1,648 & 1,648 & 1.0 & $75.0 \%$ & $65.0 \%$ \\
\hline Frankfurt (FRA) & 15 & 1,362 & 1,387 & 210 & 206 & 1,572 & 1,593 & 1.1 & $93.8 \%$ & $50.0 \%$ \\
\hline EEA Europe & 273 & 1,266 & 1,247 & 227 & 237 & 1,493 & 1,484 & 1.5 & $91.9 \%$ & $29.6 \%$ \\
\hline Middle East & 941 & 1,374 & 1,280 & 193 & 157 & 1,567 & 1,438 & 3.1 & $88.4 \%$ & $32.0 \%$ \\
\hline Non-EEA Europe & 79 & 1,272 & 1,279 & 364 & 355 & 1,636 & 1,634 & 1.8 & $94.4 \%$ & $14.0 \%$ \\
\hline Far East & 3,217 & 1,358 & 1,253 & 157 & 151 & 1,516 & 1,404 & 2.4 & $71.1 \%$ & $93.0 \%$ \\
\hline Airport-pairs & 521 & Airpor & air-days & 1,631 & & & & & & \\
\hline
\end{tabular}

The dominance of Middle Eastern and Asian hubs in South Asian and South East Asian markets, respectively, extends to the country-specific results as well. Unsurprisingly, the results from India are very similar to the ones for South Asia. Routes to Pakistan are even more clearly dominated by Middle East routings in all dimensions (flight time, connecting time, head-to-head competition). In Bangladesh, the few frequencies offered via the EEA (at Heathrow and Paris) originate at an airport (Detroit) that is not connected via the Middle East. Hence, EEA hubs face little head-on competition in the market, despite their poor travel times. A non-EEA airport like Istanbul Ataturk is the main competitor here. In regards to South East Asian countries, it is worth noting the case of Thailand, in which, again, European hubs rank ahead Middle East carriers despite their poorer average travel times. Looking into the raw data, we find that 46 out of the 63 origin markets in the Eastern US bound for Thailand have no presence of routings via the Middle East. Overall, the main conclusion from the country-specific results is that the survival of US and European carriers in these long-haul markets seems to be based on preventing the entry of Middle Eastern hubs in certain origin points, so they can operate unchallenged by competition.

Table 8. Indicators of quality of hub connections for selected country-specific markets: June 2016

\begin{tabular}{|c|c|c|c|c|c|c|c|c|c|c|}
\hline \multirow{2}{*}{$\begin{array}{l}\text { Eastern US to } \\
\text { India } \\
\text { Hub region }\end{array}$} & \multirow[t]{2}{*}{$\begin{array}{l}\text { Weekly } \\
\text { Frequencies }\end{array}$} & \multicolumn{2}{|c|}{ Avg. Flight Time (min) } & \multicolumn{2}{|c|}{$\begin{array}{c}\text { Avg. Connecting Time } \\
(\mathrm{min})\end{array}$} & \multicolumn{2}{|c|}{$\begin{array}{c}\text { Avg. Travel Time } \\
\text { (min) }\end{array}$} & \multirow{2}{*}{$\begin{array}{l}\text { Avg. } \\
\text { Bookings } \\
\text { per freq. }\end{array}$} & \multirow{2}{*}{$\begin{array}{l}\% \text { pax served in } \\
\text { competition } w / \\
\text { other regions }\end{array}$} & \multirow{2}{*}{$\begin{array}{l}\text { \% pax not slower } \\
\text { than competing } \\
\text { regions }\end{array}$} \\
\hline & & unweighted & weighted & unweighted & weighted & unweighted & weighted & & & \\
\hline$\overline{\text { EEA Europe }}$ & 1,443 & 1,091 & 1,013 & 201 & 183 & 1,292 & 1,196 & 3.2 & $90.0 \%$ & $52.1 \%$ \\
\hline Middle East & 2,580 & 1,193 & 1,062 & 140 & 145 & 1,332 & 1,206 & 4.2 & $72.0 \%$ & $61.6 \%$ \\
\hline Non-EEA Europe & 72 & 1,003 & 999 & 220 & 220 & 1,223 & 1,219 & 5.5 & $100.0 \%$ & $0.0 \%$ \\
\hline Far East & 36 & 1,360 & 1,317 & 144 & 150 & 1,505 & 1,466 & 1.8 & $98.4 \%$ & $4.7 \%$ \\
\hline Airport-pairs & 411 & Airport-pair-days & & 1,619 & & & & & & \\
\hline $\begin{array}{l}\text { Eastern US to } \\
\text { Pakistan }\end{array}$ & $\begin{array}{l}\text { Weekly } \\
\text { Frequencies }\end{array}$ & Avg. Flight Tin & $e(\min )$ & $\begin{array}{r}\text { Avg. Conne } \\
(\mathrm{mi}\end{array}$ & cting Time & $\begin{array}{r}\text { Avg. Trav } \\
\text { (mi }\end{array}$ & $\begin{array}{l}\text { vel Time } \\
\text { n) }\end{array}$ & $\begin{array}{l}\text { Avg. } \\
\text { Bookings } \\
\text { per freq. }\end{array}$ & $\begin{array}{l}\text { \% pax served in } \\
\text { competition } w / \\
\text { other regions }\end{array}$ & $\begin{array}{l}\text { \% pax not slower } \\
\text { than competing } \\
\text { regions }\end{array}$ \\
\hline Hub region & & unweighted & weighted & unweighted & weighted & unweighted & weighted & & & \\
\hline$\overline{\text { EEA Europe }}$ & 24 & 1,112 & 1,088 & 350 & 366 & 1,462 & 1,454 & 1.1 & $66.7 \%$ & $44.4 \%$ \\
\hline Middle East & 324 & 1,034 & 968 & 215 & 177 & 1,249 & 1,145 & 4.6 & $64.6 \%$ & $82.0 \%$ \\
\hline Non-EEA Europe & 75 & 1,002 & 959 & 220 & 233 & 1,222 & 1,192 & 4.1 & $93.5 \%$ & $24.4 \%$ \\
\hline
\end{tabular}




\begin{tabular}{|c|c|c|c|c|c|c|c|c|c|c|}
\hline Far East & - & - & - & - & - & - & - & - & - & - \\
\hline Airport-pairs & 68 & Airport-pair-days & & 218 & & & & & & \\
\hline $\begin{array}{l}\text { Eastern US to } \\
\text { Bangladesh }\end{array}$ & $\begin{array}{l}\text { Weekly } \\
\text { Frequencies }\end{array}$ & Avg. Flight Tin & $e(\min )$ & $\begin{array}{r}\text { Avg. Conne } \\
(\mathrm{mi}\end{array}$ & $\begin{array}{l}\text { cting Time } \\
n)\end{array}$ & $\begin{array}{r}\overline{\text { Avg. Tra }} \\
(\mathrm{mi}\end{array}$ & $\begin{array}{l}\text { vel Time } \\
\text { n) }\end{array}$ & $\begin{array}{l}\text { Avg. } \\
\text { Bookings } \\
\text { per freq. }\end{array}$ & $\begin{array}{l}\% \text { pax served in } \\
\text { competition } w / \\
\text { other regions }\end{array}$ & $\begin{array}{l}\text { \% pax not slower } \\
\text { than competing } \\
\text { regions }\end{array}$ \\
\hline Hub region & & unweighted & weighted & unweighted & weighted & unweighted & weighted & & & \\
\hline EEA Europe & 4 & 1,279 & 1,271 & 302 & 330 & 1,582 & 1,601 & 1.5 & $22.2 \%$ & $88.9 \%$ \\
\hline Middle East & 223 & 1,274 & 1,113 & 214 & 177 & 1,487 & 1,290 & 7.7 & $72.4 \%$ & $32.3 \%$ \\
\hline Non-EEA Europe & 44 & 1,190 & 1,094 & 170 & 120 & 1,359 & 1,214 & 4.8 & $95.3 \%$ & $73.9 \%$ \\
\hline Far East & 9 & 1,319 & 1,308 & 210 & 211 & 1,529 & 1,519 & 1.1 & $90.0 \%$ & $10.0 \%$ \\
\hline Airport-pairs & 33 & Airport-pair-days & & 113 & & & & & & \\
\hline $\begin{array}{l}\text { Eastern US to } \\
\text { Philippines }\end{array}$ & $\begin{array}{l}\text { Weekly } \\
\text { Frequencies }\end{array}$ & Avg. Flight Tim & $\overline{e(\min )}$ & Avg. Conne & cting Time & $\begin{array}{r}\text { Avg. Tra } \\
(\mathrm{mi}\end{array}$ & el Time & $\begin{array}{l}\text { Avg. } \\
\text { Bookings } \\
\text { per freq. }\end{array}$ & $\begin{array}{l}\text { \% pax served in } \\
\text { competition } w / \\
\text { other regions }\end{array}$ & $\begin{array}{l}\text { \% pax not slower } \\
\text { than competing } \\
\text { regions }\end{array}$ \\
\hline Hub region & & unweighted & weighted & unweighted & weighted & unweighted & weighted & & & \\
\hline EEA Europe & 12 & 1,591 & 1,605 & 233 & 226 & 1,824 & 1,831 & 1.1 & $92.3 \%$ & $7.7 \%$ \\
\hline Middle East & 173 & 1,504 & 1,408 & 279 & 217 & 1,783 & 1,624 & 2.5 & $95.0 \%$ & $7.1 \%$ \\
\hline Non-EEA Europe & 15 & 1,350 & 1,359 & 578 & 568 & 1,929 & 1,926 & 2.8 & $100.0 \%$ & $0.0 \%$ \\
\hline Far East & 1,029 & 1,332 & 1,207 & 153 & 155 & 1,485 & 1,362 & 2.7 & $74.7 \%$ & $99.8 \%$ \\
\hline Airport-pairs & 101 & Airport-pair-days & & 362 & & & & & & \\
\hline $\begin{array}{l}\text { Eastern US to } \\
\text { Singapore }\end{array}$ & $\begin{array}{l}\text { Weekly } \\
\text { Frequencies }\end{array}$ & Avg. Flight Tim & $\overline{e(\min )}$ & $\begin{array}{c}\text { Avg. Conne } \\
\text { (mi) }\end{array}$ & cting Time & $\begin{array}{r}\text { Avg. Tra } \\
(m i\end{array}$ & Time & $\begin{array}{l}\text { Avg. } \\
\text { Bookings } \\
\text { per freq. }\end{array}$ & $\begin{array}{l}\text { \% pax served in } \\
\text { competition } w / \\
\text { other regions }\end{array}$ & $\begin{array}{l}\text { \% pax not slower } \\
\text { than competing } \\
\text { regions }\end{array}$ \\
\hline Hub region & & unweighted & weighted & unweighted & weighted & unweighted & weighted & & & \\
\hline EEA Europe & 82 & 1,221 & 1,214 & 175 & 166 & 1,397 & 1,381 & 1.4 & $96.1 \%$ & $35.9 \%$ \\
\hline Middle East & 105 & 1,312 & 1,247 & 126 & 111 & 1,438 & 1,358 & 4.2 & $89.8 \%$ & $38.7 \%$ \\
\hline Non-EEA Europe & 7 & 1,292 & 1,292 & 501 & 501 & 1,793 & 1,793 & 1.0 & $100.0 \%$ & $0.0 \%$ \\
\hline Far East & 256 & 1,337 & 1,257 & 133 & 123 & 1,469 & 1,380 & 2.9 & $82.9 \%$ & $82.7 \%$ \\
\hline Airport-pairs & 43 & Airport-pair-days & & 153 & & & & & & \\
\hline $\begin{array}{l}\text { Eastern US to } \\
\text { Thailand }\end{array}$ & $\begin{array}{l}\text { Weekly } \\
\text { Frequencies }\end{array}$ & Avg. Flight Tim & $\overline{e(\min )}$ & $\begin{array}{r}\text { Avg. Conne } \\
\text { (mi) }\end{array}$ & cting Time & $\begin{array}{r}\text { Avg. Trav } \\
(m i)\end{array}$ & $\begin{array}{l}\text { vel Time } \\
n)\end{array}$ & $\begin{array}{l}\text { Avg. } \\
\text { Bookings } \\
\text { per freq. }\end{array}$ & $\begin{array}{l}\% \text { pax served in } \\
\text { competition } w / \\
\text { other regions }\end{array}$ & $\begin{array}{l}\text { \% pax not slower } \\
\text { than competing } \\
\text { regions }\end{array}$ \\
\hline Hub region & & unweighted & weighted & unweighted & weighted & unweighted & weighted & & & \\
\hline EEA Europe & 84 & 1,203 & 1,188 & 305 & 258 & 1,508 & 1,447 & 1.6 & $89.0 \%$ & $36.8 \%$ \\
\hline Middle East & 252 & 1,323 & 1,216 & 135 & 125 & 1,458 & 1,341 & 3.7 & $88.4 \%$ & $29.7 \%$ \\
\hline Non-EEA Europe & 26 & 1,199 & 1,190 & 304 & 277 & 1,503 & 1,467 & 1.7 & $97.7 \%$ & $2.3 \%$ \\
\hline Far East & 475 & 1,354 & 1,249 & 134 & 119 & 1,488 & 1,368 & 2.5 & $84.3 \%$ & $87.4 \%$ \\
\hline Airport-pairs & 91 & Airport-pair-days & & 283 & & & & & & \\
\hline $\begin{array}{l}\text { Eastern US to } \\
\text { Vietnam }\end{array}$ & $\begin{array}{l}\text { Weekly } \\
\text { Frequencies }\end{array}$ & Avg. Flight Tim & $e(\min )$ & $\begin{array}{r}\text { Avg. Conne } \\
\text { (mil }\end{array}$ & cting Time & $\begin{array}{r}\text { Avg. Tra } \\
(m i\end{array}$ & $\begin{array}{l}\text { vel Time } \\
\text { n) }\end{array}$ & $\begin{array}{l}\text { Avg. } \\
\text { Bookings } \\
\text { per freq. }\end{array}$ & $\begin{array}{l}\% \text { pax served in } \\
\text { competition } w / \\
\text { other regions }\end{array}$ & $\begin{array}{l}\% \text { pax not slower } \\
\text { than competing } \\
\text { regions }\end{array}$ \\
\hline Hub region & & unweighted & weighted & unweighted & weighted & unweighted & eighted & & & \\
\hline$\overline{\text { EEA Europe }}$ & 25 & 1,227 & 1,215 & 197 & 191 & 1,424 & 1,405 & 1.6 & $87.8 \%$ & $19.5 \%$ \\
\hline Middle East & 73 & 1,348 & 1,258 & 202 & 126 & 1,550 & 1,383 & 3.3 & $96.7 \%$ & $44.9 \%$ \\
\hline Non-EEA Europe & 3 & 1,225 & 1,225 & 437 & 437 & 1,662 & 1,662 & 1.0 & $66.7 \%$ & $33.3 \%$ \\
\hline Far East & 732 & 1,368 & 1,277 & 164 & 151 & 1,532 & 1,427 & 2.3 & $62.0 \%$ & $93.0 \%$ \\
\hline Airport-pairs & 97 & Airport-pair-days & & 306 & & & & & & \\
\hline
\end{tabular}

These results show that the concerns about the threat posed by Middle Eastern carriers to the traffic of US airlines and their alliance partners are justified, primarily in the market to South Asian countries. In spite of that, any calls from US carriers to introduce protectionist measures could not be justified by the argument that Middle East hubs offer slow or excessively inconvenient hub connections in markets to Asian countries. This has been disproven by our analysis: while travelling via the Middle East leads to slightly higher geographical detours than via Europe or the Far East, the excess flight time is compensated with shorter connecting times at hubs like Dubai. Beyond protectionist measures, potential solutions to this problem include achieving a better flight coordination to achieve more competitive transfers via European hubs. This also points to the need for the relevant European hub carriers to develop strategic partnerships with airlines from these Asian regions to increase the number of available frequencies.

\section{SUMMARY AND CONCLUSIONS}

In the context provided by the US carrier's claims about losing traffic to Middle Eastern carriers, the purpose of this study is to ascertain whether Middle Eastern hubs are threatening the competitive position of European and Asian hubs in the air transport markets from the Eastern US to South Asia and South East Asia. While the general threat to established players posed by fast- 
growing airports and airlines in the Middle East has been analysed in previous studies, little has been published with data from 2013 onwards to show Middle Eastern airports surpassing European or Asian hubs in terms of intercontinental passenger connections. To fill this gap, we look at the change in market shares between 2012 and 2016 of the top hubs in the mentioned markets. Furthermore, several indicators of quality of hub connections are provided, including average connecting times and average travel times. These quality indicators, calculated by combining data on airline schedules and passenger bookings, can be disaggregated by geographical market, which is a novel approach as well.

Our results present novel evidence that Middle Eastern hubs have increased their share of connections at the expense of the market shares of European airports and, in fact, have already become market leaders in some of the selected routes. In the South Asia market, the increase in Middle East connections is parallel to market growth as both non-stop connections and indirect traffic via Europe remains stable. Furthermore, we show that Middle Eastern hubs can offer competitive options in terms of total travel time due to short connecting times. Regarding the South East Asia market, Far Eastern hubs have actually increased their market share, but a leakage towards indirect travel options via the Middle East is also present. In relation to this, it is found that Dubai provides lower average travel times than the market leader Tokyo Narita. At a country level, Middle East carriers dominate European hubs as well, except in routes to Thailand, where the survival of US and European carriers benefits from the absence of Middle Eastern hubs in certain points of origin, for which there is little to no hub competition. In view of these results, it is clear that the concerns about the threat posed by Middle Eastern carriers to the traffic of US airlines and their alliance partners are justified. However, any calls from US carriers to introduce protectionist measures cannot be justified by the argument that Middle East hubs offer slow hub connections in markets to Asia. This has been disproven by our analysis.

This study is limited by data availability. The traffic trends presented in our results section are based on weekly data only for June 2012 and June 2016. Demand data for intermediate years is compromised by disrupting events like the runway renovations at Dubai Airport in 2014 so its inclusion would have been problematic. Furthermore, while one may argue that seasonal variations may affect the airport rankings, using data from the US Department of Transportation (T-100 database) we can establish that the second quarter of 2016 is the one that most closely represents annual average traffic in international markets. Hence, our results should at least not deviate significantly from annual averages. We are also limited by the lack of data on prices and booking classes, as well as on-time performance data, which would allow for a more comprehensive comparative analysis. Further research may also focus on comparing hub performance in the intercontinental markets between Europe and Asia or Africa, where intense competition between European and Middle-Eastern hubs is also present. This will require incorporating direct connections into the analysis, which are largely absent from the present research that focuses mostly on hub connections. At the same time, the scope of our approach to combine supply and demand data can be expanded to cover both domestic and international passenger connections.

\section{ACKNOWLEDGMENTS}

The authors wish to thank the editor and three anonymous referees for the helpful comments to the earlier versions of this manuscript. 


\section{REFERENCES}

ACI, 2016. Passenger Traffic. [Online]

Available at: http://www.aci.aero/Data-Centre/Annual-Traffic-Data/Passengers/2011-final

[Accessed 2016].

Allroggen, F., Wittmann, D., and Malina, R., 2015. How air transport connects the world - A new metric of air connectivity and its evolution between 1990 and 2012. Transportation research Part E 80, 184201.

Burghouwt, G., 2007. Airline network development in Europe and its implications for airport planning. Aldershot: Ashgate.

Burghouwt, G. \& De Wit, J., 2005. The temporal configuration of airline networks in Europe. Journal of Air Transport Management, 11(3), pp. 185-198.

Cronrath, E., Arndt, A. \& Zoch, A., 2008. Does size matter? The importance of airports in the European and German air transport network. Athens, Air Transport Research Society Conference.

de Wit, J. G., 2014. Unlevel playing field? Ah yes, you mean protectionism. Journal of Air Transport Management, 41(0), pp. 22-29.

Doganis, R., 2009. Flying Off Course: Airline Economics and Marketing. 4th ed. Abingdon, England, UK: Routledge.

Dresner, M. et al., 2015. The impact of Gulf carrier competition on U.S. airlines. Transportation Research Part A, Issue 79, pp. 31-41.

Durganhee, A., 2013. Gulf Airlines Shake Up Aviation Alliances. [Online] Available at: http://edition.cnn.com/2013/01/16/travel/gulf-airlines-alliances/ [Accessed May 2016].

Grimme, W., 2011. The growth of Arabian airlines from a German perspective - A study of the impacts of new air services to Arabia. Journal of Air Transport Management, 17(0), pp. 333-338.

Grosche, T. \& Klophaus, R., 2015. Hubs at risk: Exposure of Europe's largest hubs to competition on transfer city Pairs. Transport Policy, Issue 43, pp. 55-60.

Guimerà, R., Mossa, S., Turtschi, A. \& Amaral, L. A. N., 2005. The worldwide air transportation network: Anomalous centrality, community structure, and cities' global roles. Proceedings of the National Academy of Sciences of the United States of America, 102(22), pp. 7794-7799.

Kindergan, A., 2015. Revisiting: The rise of the Gulf Carriers. [Online] Available at: https://www.thefinancialist.com/the-rise-of-the-gulf-carriers/ [Accessed May 2016].

Malighetti, P., Paleari, S. \& Redondi, R., 2008. Connectivity of the European airport network: "Self-help hubbing" and business implications. Journal of Air Transport Management, Volume 14, pp. 53-65.

Morgan Stanley, 2015. Global Airlines Insight: Passengers are Not Proprietary - The Gulf Carrier Challenge, s.l.: Morgan Stanley Research.

O'Connell, J. F., 2011. The rise of the Arabian Gulf carriers: An insight into the business model of Emirates Airline. Journal of Air Transport Management, Issue 17, pp. 339-346.

Paleari, S., Redondi, R. \& Malighetti, P., 2008. A comparative study of airport connectivity in China, Europe and US: which network provides the best service to passengers? Transportation Research Part E: Logistics and Transportation Review 46 (2), pp.198-210

Partnership for Open and Fair Skies, 2015. Airline Employees Urge the Obama Administration to Confront Gulf Carriers Subsidization in New Video. [Online] Available at: http://www.openandfairskies.com/press-releases/airline-employees-urge-the-obamaadministration-to-confront-gulf-carriers-subsidization-in-new-video/ [Accessed 17 March 2016].

Redondi, R., Malighetti, P. \& Paleari, S., 2011. Hub competition and travel times in the world-wide airport network. Journal of Transport Geography, Issue 19, pp. 1260-1271.

Redondi, R., Malighetti, P. \& Paleari, S., 2011. New Routes and Airport Connectivity. Networks and Spatial Economics, Volume 11, pp. 713-725. 
Rodrìguez-Dèniz, H., Suau-Sanchez, P. \& Voltes-Dorta, A., 2013. Classifying airports according to theit hub dimensions: an application to the US domestic network. Journal of Transport Geography, Issue 33, pp. 188-195.

Seredynski, A., Rothlauf, F. \& Grosche, T., 2014. An airline connection builder using maximum connection lag with greedy parameter selection. Journal of Air Transport Management, 36(0), pp. $120-128$.

Shaw, S.-L., 1993. Hub structures of major US passenger airlines. Journal of Transport Geography, 1(1), pp. 47-58.

Shaw, S.-L. \& Ivy, R. L., 1994. Airline mergers and their effect on network structure. Journal of Transport Geography, 2(4), pp. 234-246.

Suau-Sanchez, P., Voltes-Dorta, A. \& Rodríguez-Déniz, H., 2016. The role of London airports in providing connectivity for the UK: regional dependence on foreign hubs. Journal of Transport Geography, Volume 50, pp. 94-104.

The Telegraph, 2015. The incredible rise of Dubai as the world's air travel hub. [Online] Available at: http://www.telegraph.co.uk/travel/destinations/middle-east/united-arabemirates/dubai/articles/The-incredible-rise-of-Dubai-as-the-worlds-air-travel-hub/ [Accessed 17 March 2016].

Veldhuis, J., 1997. The competitive position of airline networks. Journal of Air Transport Management, 3(4), pp. 181-188.

Voltes-Dorta, A., Rodríguez-Déniz, H., and Suau-Sanchez, P. 2017. Vulnerability of the European air transport network to major airport closures from the perspective of passenger delays: Ranking the most critical airports. Transportation Research Part A: Policy and Practice 96. 119-145.

Zhang, B., 2015. The Middle East's 3 best airlines have infuriated their US competitors. [Online] Available at: http://uk.businessinsider.com/middle-eastern-us-airlines-dispute-future-of-air-travel 
APPENDIX A. Connections-building algorithm

For each MIDT record (See Table B1), a search is made for all available weekly flights between the airports. The flights are then filtered by the codes of the published airline and its partners.

Table B1. Sample MIDT record ( $1^{\text {st }}$ week of June 2016)

\begin{tabular}{llllll}
\hline Published Airline & Origin & Gateway 1 & Gateway 2 & Destination & Passengers \\
\hline BA (British Airways) & JFK (New York) & LHR (Heathrow) & - & BOM (Mumbai) & 234 \\
\hline
\end{tabular}

Using a SAS algorithm, best weekly flight connections are built on the following restrictions (adapted from Seredynski et al., 2014): a) the published minimum connecting times (minct) must be met, b) the maximum connecting time (maxct) is arbitrarily set at one hour above the shortest weekly connection time (as in Voltes-Dorta et al., 2017) ${ }^{5}$, c) passengers on each first-leg flight prefer the alternative with the shortest travel time, and d) passengers on each final-leg flight also prefer the shortest travel times. For the example in Table B1, the published minct was 60 min, which matches the best weekly connection time. Thus, the maxct is $120 \mathrm{~min}$. These restrictions leave the two selected connections shown in Table B2 (bold numbers) for Monday departures.

Table B2. Selected flight connections for the sample MIDT record in the first-stage (Monday departures from JFK)

\begin{tabular}{|c|c|c|c|c|}
\hline Connecting times $(\mathrm{min})$ & Arrival time & I Departure time & $\begin{array}{l}\text { LHR-BOM } \\
21: 25\end{array}$ & $10: 30+1$ \\
\hline \multirow{6}{*}{ 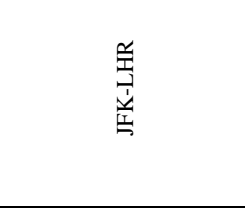 } & $19: 45$ & & 100 & 885 \\
\hline & $22: 10$ & & & 740 \\
\hline & $8 \cdot 15+1$ & & & 135 \\
\hline & $\begin{array}{l}0.15+1 \\
8: 55+1\end{array}$ & & & $\frac{95}{95}$ \\
\hline & $9: 30+1$ & & & 60 \\
\hline & $10: 30+1$ & & & 0 \\
\hline
\end{tabular}

Notes: Minimum Connecting Time $=60$ min. Maximum Connecting Time $=120$ min. Bold indicates selected connections.

After the flight combinations are selected, the number of passengers in the MIDT record is distributed among them according to seat capacity (Table B3), which is determined by the minimum number of seats across all sectors. The proportion of passengers allocated to each travel option is equal to the proportion of its seat capacity to total capacity. In order not to lose or gain bookings due to rounding, results are rounded up or down randomly until all MIDT passengers are allocated, always giving preference to fastest flight connections.

Table B3. Valid flight combinations and allocation of demand according to seat capacity

\begin{tabular}{|c|c|c|c|c|c|c|c|c|c|c|c|c|c|c|}
\hline \multirow[b]{2}{*}{ Day } & \multicolumn{5}{|c|}{ Flight 1: JFK-LHR } & \multicolumn{5}{|c|}{ Flight 2: LHR-BOM } & \multicolumn{4}{|c|}{ Full itinerary } \\
\hline & Airline & $\begin{array}{l}\text { Flight } \\
\text { No. }\end{array}$ & Dep. & Arr. & Seats & Airline & $\begin{array}{l}\text { Flight } \\
\text { No. }\end{array}$ & Dep. & Arr. & Seats & $\begin{array}{c}\text { Seat } \\
\text { capacity }\end{array}$ & $\begin{array}{l}\text { MIDT } \\
\text { Pax. }\end{array}$ & $\begin{array}{l}\text { Connecting } \\
\text { Time (min) }\end{array}$ & $\begin{array}{c}\text { Travel } \\
\text { Time (min) }\end{array}$ \\
\hline$\overline{M o n}$ & $\overline{\mathrm{BA}}$ & 178 & $7: 55$ & $19: 45$ & 275 & $\overline{\mathrm{BA}}$ & 199 & $21: 25$ & $11: 10^{+1}$ & 297 & 275 & 20 & 100 & 1065 \\
\hline Mon & BA & 114 & $21: 30$ & $9: 30^{+1}$ & 226 & BA & 139 & $10: 30^{+1}$ & $23: 55^{+1}$ & 297 & 226 & 15 & 60 & 1015 \\
\hline Tue & BA & 178 & $7: 55$ & $19: 45$ & 275 & BA & 199 & $21: 25$ & $11: 10^{+1}$ & 297 & 275 & 20 & 100 & 1065 \\
\hline Tue & BA & 114 & $21: 30$ & $9: 30^{+1}$ & 337 & $\mathrm{BA}$ & 139 & $10: 30^{+1}$ & $23: 55^{+1}$ & 297 & 297 & 22 & 60 & 1015 \\
\hline Sun & $\mathrm{BA}$ & 178 & $7: 55$ & $19: 45$ & 275 & $\mathrm{BA}$ & 139 & $21: 25$ & $11: 10^{+1}$ & 226 & 226 & 16 & 95 & 1060 \\
\hline
\end{tabular}

After a first round of processing, the resulting travel records are aggregated by flight number and departure date in order to check whether the number of passengers in all OD markets assigned to each individual flight does not exceed the seat capacity of the aircraft. Passengers over capacity are taken out of the travel records and brought into new rounds of processing with updated seat capacities in the schedules dataset. For this paper, two sequential rounds were enough to ensure that $96 \%$ of all itineraries in the MIDT dataset were allocated to valid flight combinations.

\footnotetext{
${ }^{5}$ This helps to discard connections that require excessive layovers. The 1-hour window prevents excessive traffic from being allocated to the optimal connections, which causes capacity problems. Expanding the time window will have the undesirable effect of assigning too many passengers to longer connections while there is still capacity in the faster ones. Still, the slower connections can catch passengers in the second-round of processing.
} 
APPENDIX B. Additional country-specific results

\begin{tabular}{|c|c|c|c|c|c|c|c|c|c|c|}
\hline \multirow{2}{*}{$\begin{array}{l}\text { Eastern US to } \\
\text { Maldives } \\
\text { Hub region } \\
\end{array}$} & \multirow[t]{2}{*}{$\begin{array}{l}\text { Weekly } \\
\text { Frequencies }\end{array}$} & \multicolumn{2}{|c|}{ Avg. Flight Time (min) } & \multicolumn{2}{|c|}{$\begin{array}{c}\text { Avg. Connecting Time } \\
\text { (min) }\end{array}$} & \multicolumn{2}{|c|}{$\begin{array}{l}\text { Avg. Travel Time } \\
(\text { min })\end{array}$} & \multirow[t]{2}{*}{$\begin{array}{l}\text { Avg. } \\
\text { Bookings per } \\
\text { frequency }\end{array}$} & \multirow[t]{2}{*}{$\begin{array}{l}\% \text { pax served in } \\
\text { competition with } \\
\text { other regions }\end{array}$} & \multirow[t]{2}{*}{$\begin{array}{l}\text { \% pax not } \\
\text { slower than } \\
\text { competing } \\
\text { regions }\end{array}$} \\
\hline & & unweighted & weighted & unweighted & weighted & unweighted & weighted & & & \\
\hline EEA Europe & 1 & 1,280 & 1,280 & 230 & 230 & 1,510 & 1,510 & 1.0 & $100.0 \%$ & $100.0 \%$ \\
\hline Middle East & 31 & 1,062 & 1,049 & 161 & 144 & 1,224 & 1,193 & 1.5 & $4.4 \%$ & $100.0 \%$ \\
\hline Von-EEA Europe & 3 & 1,140 & 1,140 & 560 & 560 & 1,700 & 1,700 & 1.0 & $0.0 \%$ & $100.0 \%$ \\
\hline Far East & 1 & 1,325 & 1,325 & 715 & 715 & 2,040 & 2,040 & 1.0 & $100.0 \%$ & $0.0 \%$ \\
\hline Airport-pairs & 8 & \multicolumn{2}{|l|}{ Airport-pair-days } & 23 & & & & & & \\
\hline $\begin{array}{l}\text { Eastern US to Sri } \\
\text { Lanka }\end{array}$ & $\begin{array}{l}\text { Weekly } \\
\text { Frequencies }\end{array}$ & \multicolumn{2}{|c|}{ Avg. Flight Time (min) } & \multicolumn{2}{|c|}{$\begin{array}{c}\text { Avg. Connecting Time } \\
(\text { min })\end{array}$} & \multicolumn{2}{|c|}{$\begin{array}{l}\text { Avg. Travel Time } \\
\text { (min) }\end{array}$} & $\begin{array}{l}\text { Avg. } \\
\text { Bookings per } \\
\text { frequency }\end{array}$ & $\begin{array}{l}\% \text { pax served in } \\
\text { competition with } \\
\text { other regions }\end{array}$ & \multirow[t]{2}{*}{$\begin{array}{l}\text { \% pax not } \\
\text { slower than } \\
\text { competing } \\
\text { regions }\end{array}$} \\
\hline Hub region & & unweighted & weighted & unweighted & weighted & unweighted & weighted & & & \\
\hline EEA Europe & 27 & 1,140 & 1,140 & 443 & 443 & 1,583 & 1,583 & 1.0 & $57.1 \%$ & $50.0 \%$ \\
\hline iiddl & 108 & 1,155 & 1,092 & 150 & 167 & 1,305 & 1,259 & 2.6 & $72.6 \%$ & $83.3 \%$ \\
\hline Von-EEA Europe & - & - & & - & - & - & - & - & - & - \\
\hline Far East & 6 & 1,280 & 1,280 & 95 & 95 & 1,375 & 1,375 & 1.8 & $100.0 \%$ & $0.0 \%$ \\
\hline Airport-pairs & 26 & \multirow{2}{*}{\multicolumn{2}{|c|}{$\begin{array}{l}\text { Airport-pair-days } \\
\text { Avg. Flight Time (min) }\end{array}$}} & \multicolumn{2}{|l|}{80} & & & & & \\
\hline $\begin{array}{l}\text { Eastern US to } \\
\text { Cambodia }\end{array}$ & \multirow[t]{2}{*}{$\begin{array}{l}\text { Weekly } \\
\text { Frequencies }\end{array}$} & & & \multicolumn{2}{|c|}{$\begin{array}{c}\text { Avg. Connecting Time } \\
(\text { min })\end{array}$} & \multicolumn{2}{|c|}{$\begin{array}{l}\text { Avg. Travel Time } \\
\text { (min) }\end{array}$} & \multirow[t]{2}{*}{$\begin{array}{l}\text { Avg. } \\
\text { Bookings per } \\
\text { frequency }\end{array}$} & $\begin{array}{l}\text { \% pax served in } \\
\text { competition with } \\
\text { other regions }\end{array}$ & $\begin{array}{l}\% \text { pax not } \\
\text { slower than } \\
\text { competing } \\
\text { regions }\end{array}$ \\
\hline Hub region & & unweighted & weighted & unweighted & weighted & unweighted & weighted & & & \\
\hline EA Europe & 4 & 1,638 & 1,638 & 242 & 242 & 1,880 & 1,880 & 1.0 & $100.0 \%$ & $0.0 \%$ \\
\hline Iiddle East & 7 & 1,504 & 1,504 & 137 & 137 & 1,641 & 1,641 & 1.0 & $85.7 \%$ & $14.3 \%$ \\
\hline Europe & - & - & - & - & - & - & - & - & - & - \\
\hline Far East & 181 & 1,379 & 1,284 & 183 & 220 & 1,562 & 1,504 & 1.9 & $17.0 \%$ & $100.0 \%$ \\
\hline Airport-pairs & 37 & Airport-pair-days & & 104 & & & & & & \\
\hline $\begin{array}{l}\text { Eastern US to } \\
\text { Indonesia }\end{array}$ & $\begin{array}{l}\text { Weekly } \\
\text { Frequencies }\end{array}$ & Avg. Flight Tim & $n e(\min )$ & $\begin{array}{r}\text { Avg. Connc } \\
(m)\end{array}$ & ing Time & $\begin{array}{l}\text { Avg. Trav } \\
\text { (mir }\end{array}$ & $\begin{array}{l}\text { vel Time } \\
\text { n) }\end{array}$ & $\begin{array}{l}\text { Avg. } \\
\text { Bookings per } \\
\text { frequency }\end{array}$ & $\begin{array}{l}\% \text { pax served in } \\
\text { competition with } \\
\text { other regions }\end{array}$ & $\begin{array}{l}\% \text { pax not } \\
\text { slower than } \\
\text { competing } \\
\text { regions }\end{array}$ \\
\hline Hub region & & hted & ghted & ghted & hted & eighted & eighted & & & \\
\hline EEA Europe & 27 & 1,411 & 1,345 & 242 & 416 & 1,653 & 1,761 & 2.2 & $92.2 \%$ & $12.5 \%$ \\
\hline$s t$ & 167 & 1 & & 2 & 229 & 1,669 & 1 , & 2.7 & $81.7 \%$ & $44.2 \%$ \\
\hline rope & 8 & 1,347 & 1,347 & 574 & 574 & 1,922 & 1,922 & 1.0 & $100.0 \%$ & $0.0 \%$ \\
\hline Far East & 317 & 1,452 & 1,381 & 207 & 198 & 1,659 & 1,580 & 1.8 & $76.1 \%$ & $82.3 \%$ \\
\hline Airport-pairs & 71 & Airport-pair-days & & 204 & & & & & & \\
\hline $\begin{array}{l}\text { Eastern US to } \\
\text { Laos }\end{array}$ & $\begin{array}{l}\text { Weekly } \\
\text { Frequencies }\end{array}$ & Avg. Flight Tim & $\overline{n e(\min )}$ & $\begin{array}{r}\text { Avg. Conne } \\
(m i\end{array}$ & $\begin{array}{l}\text { cting Time } \\
\text { n) }\end{array}$ & $\begin{array}{r}\text { Avg. Trav } \\
(\text { mir }\end{array}$ & $\begin{array}{l}\text { vel Time } \\
\text { n) }\end{array}$ & $\begin{array}{l}\text { Avg. } \\
\text { Bookings per } \\
\text { frequency }\end{array}$ & $\begin{array}{l}\text { \% pax served in } \\
\text { competition with } \\
\text { other regions }\end{array}$ & $\begin{array}{l}\text { \% pax not } \\
\text { slower than } \\
\text { competing } \\
\text { regions }\end{array}$ \\
\hline Hub region & & unweighted & weighted & unweighted & weighted & unweighted & weighted & & & \\
\hline & - & - & - & - & - & - & - & - & - & - \\
\hline ist & 10 & 1,374 & 1,373 & 179 & 180 & 1,554 & 1,553 & 1.2 & $0.0 \%$ & $100.0 \%$ \\
\hline pe & - & - & - & - & - & - & - & - & - & - \\
\hline Far East & 7 & 1,251 & 1,244 & 106 & 102 & 1,356 & 1,346 & 1.1 & $0.0 \%$ & $100.0 \%$ \\
\hline Airport-pairs & 8 & Airport-pair-days & & 17 & & & & & & \\
\hline $\begin{array}{l}\text { Eastern US to } \\
\text { Malaysia }\end{array}$ & $\begin{array}{l}\text { Weekly } \\
\text { Frequencies }\end{array}$ & Avg. Flight Tim & $n e(\min )$ & $\begin{array}{r}\text { Avg. Conne } \\
(m i\end{array}$ & $\begin{array}{l}\text { cting Time } \\
\text { n) }\end{array}$ & $\begin{array}{r}\text { Avg. Trav } \\
(\text { mir }\end{array}$ & $\begin{array}{l}\text { vel Time } \\
\text { (n) }\end{array}$ & $\begin{array}{l}\text { Avg. } \\
\text { Bookings per } \\
\text { frequency }\end{array}$ & $\begin{array}{l}\% \text { pax served in } \\
\text { competition with } \\
\text { other regions }\end{array}$ & $\begin{array}{l}\% \text { pax not } \\
\text { slower than } \\
\text { competing } \\
\text { regions }\end{array}$ \\
\hline 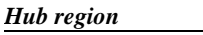 & & eighted & ighted & unweighted & ighted & veighted & weighted & & & \\
\hline EA Europe & 33 & 1,252 & 1,246 & 222 & 213 & 1,474 & 1,459 & 1.1 & $89.7 \%$ & $30.8 \%$ \\
\hline & 128 & & & & 160 & & & & & \\
\hline$e$ & 20 & 1,277 & 1 & & 30 & 1,417 & & 2. & $84.6 \%$ & $46.2 \%$ \\
\hline Far East & 167 & 1,328 & 1,274 & 154 & 145 & 1,482 & 1,419 & 1.8 & $71.6 \%$ & $86.4 \%$ \\
\hline Airport-pairs & 52 & Airport-pair-days & & 144 & & & & & & \\
\hline $\begin{array}{l}\text { Eastern US to } \\
\text { Myanmar }\end{array}$ & $\begin{array}{l}\text { Weekly } \\
\text { Frequencies }\end{array}$ & Avg. Flight Tim & $n e(\min )$ & $\begin{array}{r}\text { Avg. Conne } \\
\text { (mi }\end{array}$ & $\begin{array}{l}\text { cting Time } \\
\text { i) }\end{array}$ & $\begin{array}{l}\text { Avg. Trav } \\
(\text { mir }\end{array}$ & $\begin{array}{l}\text { vel Time } \\
\text { n) }\end{array}$ & $\begin{array}{l}\text { Avg. } \\
\text { Bookings per } \\
\text { frequency }\end{array}$ & $\begin{array}{l}\text { \% pax served in } \\
\text { competition with } \\
\text { other regions }\end{array}$ & $\begin{array}{l}\% \text { pax not } \\
\text { slower than } \\
\text { competing } \\
\text { regions }\end{array}$ \\
\hline Hub region & & unweighted & weighted & unweighted & weighted & unweighted & weighted & & & \\
\hline & 5 & 1,5 & 1,561 & 140 & 140 & 1,701 & 1,701 & 1. & $100.0 \%$ & $0.0 \%$ \\
\hline & 26 & 1,384 & 1,285 & 178 & 179 & 1,563 & 1,464 & 1.6 & $41.5 \%$ & $61.0 \%$ \\
\hline Von-EEA Europe & - & - & - & - & - & - & - & - & & - \\
\hline Far East & 52 & 1,382 & 1,282 & 140 & 145 & 1,521 & 1,427 & 2.2 & $35.4 \%$ & $100.0 \%$ \\
\hline Airport-pairs & 18 & Airport-pair-days & & 56 & & & & & & \\
\hline
\end{tabular}


2017-10-09

\section{A comparative analysis of hub}

connections of European and Asian airports against Middle Eastern hubs in intercontinental markets

\section{Piltz, Christopher}

\section{Elsevier}

Piltz C, Voltes-Dorta A, Suau-Sanchez P, A comparative analysis of hub connections of European and Asian airports against Middle Eastern hubs in intercontinental markets, Journal of Air Transport Management, Volume 66, January 2018, pp. 1-12

http://dx.doi.org/10.1016/j.jairtraman.2017.09.006

Downloaded from Cranfield Library Services E-Repository 